\title{
Ocular transmission of SARS-CoV-2
}

\section{Transmisión ocular del SARS-CoV-2}

\author{
Claudia Maldonado-Correa* and Claudia Soto-Idrogo
}

Instituto Nacional de Oftalmología, Lima, Peru

\section{Dear Editor,}

In the March-April 2021 edition, Ruiz Morales performs a review on ocular transmission to develop COVID-19 ${ }^{1}$, and in this regard, we raise the following considerations.

SARS-CoV-2 is a virus that spreads rapidly and to date has infected more than $119,603,761$ people, with 2,649,722 deaths worldwide? ${ }^{2}$.

Regarding ocular transmission, the evidence is still controversial. While it is true that it has been shown that there are angiotensin-converting enzyme 2 receptors in the cornea, making the eyes a possible transmission route, studies reveal that only $3 \%$ of patients have conjunctival swab samples positive for SARSCoV-2, and it has been reported that only $1 \%$ had a diagnosis of conjunctivitis or conjunctival congestion as an initial symptom ${ }^{3}$. Also, it has been found that in patients with COVID-19, the presence of ocular symptoms has been associated with increased inflammatory markers, but does not correlate with clinical symptoms or images ${ }^{4}$. These data suggest that, although transmission is possible, it is unlikely, and those patients with ocular symptoms may develop increased laboratory parameters, but studies are needed to correlate this with other severity characteristics.
With the aforementioned, we can indicate that there are other proven routes of transmission, of which the most frequent is the airborne transmission of SARSCOV-2 through respiratory droplets and aerosols. Taking this premise into account, an attempt is being made to standardize preventive measures to reduce the transmission of the virus, including frequent hand washing, social distancing of at least 1 meter and the use of masks. The types of masks currently available are broadly of two types: medical and non-medical. Non-medical masks can be made of cloth, they are recommended to have three layers and are indicated for the general population, while medical masks (for example, N95 respirators) are for health personnel, but also for people with confirmed or suspected COVID-19, and current World Health Organization recommendations state that those with debilitating illnesses could also use them; this is an important factor because it is a population at high risk of developing severe forms of the infection ${ }^{2}$. On the other hand, given the possible ocular transmission of SARS-COV-2, face shields could be used, as well as protective glasses, but the evidence is still uncertain. The current recommendations are aimed at mass vaccination, which at the moment is gradual with the different vaccines available on the market ${ }^{5}$. 
For the aforementioned reasons, the update of possible measures to prevent COVID-19 should continue to be promoted to slow down the spread of this virus, which has caused high morbidity and mortality so far.

\section{Conflicts of interest}

The authors declare no conflicts of interest.

\section{Ethical disclosures}

Protection of human and animal subjects. The authors declare that no experiments were performed on humans or animals for this study.
Confidentiality of data. The authors declare that no patient data appear in this article.

Right to privacy and informed consent. The authors declare that no patient data appear in this article.

\section{References}

1. Ruiz-Morales M. La ruta ocular, un riesgo para desarrollar COVID-19. Rev Mex Oftalmol. 2021; 95: 93-4.

2. World Health Organization. Coronavirus (COVID-19) Dashboard. (Consultado el 17 marzo 2021.) Disponible en: https://covid19.who.int/

3. Cao K, Kline B, Ying G, II N. Current evidence of 2019 novel coronavirus disease (COVID-19) ocular transmission: a systematic review and meta-analysis. Biomed Res Int. 2020;2020:7605453.

4. Wu P, Duan F, Luo C, Liu Q, Qu X, Liang L, et al. Characteristics of ocular findings of patients with coronavirus disease 2019 (COVID-19) in Hubei Province, China. JAMA Ophthalmol. 2020;138:575-8.

5. Marra AR, Edmond MB, Popescu SV, Perencevich EN. Examining the need for eye protection for coronavirus disease 2019 (COVID-19) prevention in the community. Infect Control Hosp Epidemiol. 2020;1-2. 